\title{
AIR TAXI FLIGHT SHARING
}

\author{
Wojciech G. Miksa \\ Łukasiewicz Research Network - Institute of Aviation, Al. Krakowska 110/114, 02-256 Warsaw, Poland \\ kf83a@wp.pl•ORCID: 0000-0002-7441-4113
}

\begin{abstract}
In traditional air taxi model, flight route and timing are assigned to every order individually, resulting in minimum utilization of seats, maximum number of empty legs and elevated price levels. Sharing flights, when possible, allow decreasing number of empty seats and distributing cost of flight among customers. Challenges to overcome are varying timing needs of customers and volatility of demand. This article investigates possibilities of synchronizing passenger orders. The proposed passenger pooling model replaces specific flight timing on order with constraints: latest arrival and earliest departure to provide room for coordination of orders, backed by web-based ICT. Theoretical test cases calculations verify the concept and compare it with traditional full on-demand and scheduled operations.
\end{abstract}

Keywords: air taxi; service model; shared service; load factor.

\section{INTRODUCTION}

Globalizing and growing economy strengthens the need for travel. Forecasts indicate growth of demand for business travel [1], [2]. Transportation speed is invaluable quality for effectively handling professional matters, as many of them are urgent. Aircraft save passengers their precious time and minimize number of unproductive hours wasted during journeys [3]. Air transport is the mode of choice for long distance, international trips. Less populated or less developed destinations though may be important from business perspective due to location of valuable resources, cheap land or low wage workforce, often lack adequate connections. Low passenger flows do not justify cost of maintaining regular connections while deficiencies in transport infrastructure development are a barrier for fast means of transport. A solution to address these needs can be air taxi or Small Aircraft Transport (SAT) concept, assuming use of aircraft between 3 and 14 (US research [4]) or 19 (EU research [5]) that can operate from less developed aerodromes than airliners. Such transport can fulfill demand outside the big cities, connecting more communities in less time [6]. Research of demand indicates substantial potential demand for SAT services in Europe [6], [7], [8]. In the perspective of the future, SAT is particularly interesting, as small aircraft are more feasible for implementation of full-electric or hybrid electric propulsion system [9] that can decrease emissions and alleviate aircraft industry dependence on oil prices.

Small passenger capacity renders service significantly vulnerable to variations in demand. Every seat count, for 3 to 19 passenger seat airplanes, each one constitutes 33 down to 5 percent of the load factor. Such sharp, highly non-linear variation in per passenger cost is challenging for ticket pricing (see Figure 1, example costs were calculated on the basis of Roskam [10] methodology with small improvements proposed in the EPATS project [11]). 


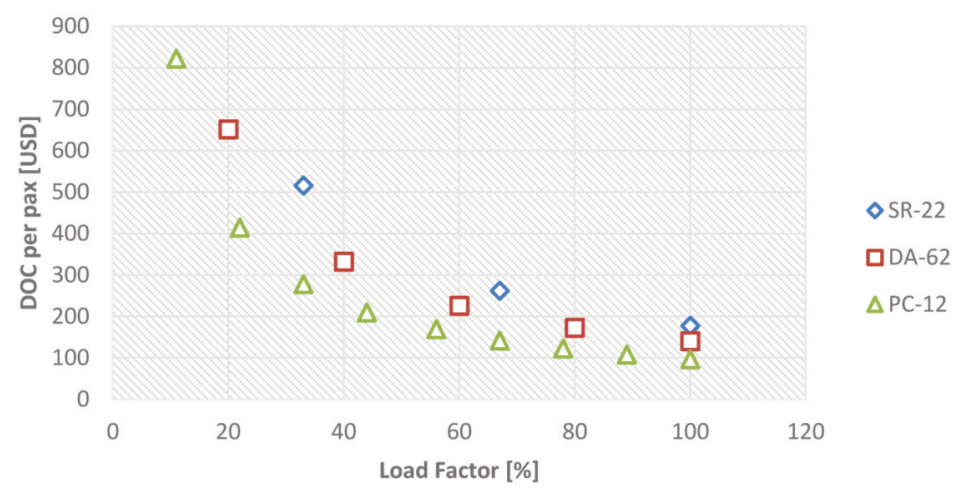

Fig. 1. Example Direct Operating Cost (DOC) per passenger (pax) variation with load factor $(\mathrm{LD})$ on a $616 \mathrm{~km}$ route.

In the full on-demand air taxi service model, timing and routing are tailored to every order individually. Inability to share seats in flights results in low average load factor, high flight cost per passenger and high price of ticket. Other source of undesired costs are empty flight legs that may arise when aircraft need to get to passenger origin and/or from passenger destination to aircraft base airfield. Opportunities for improvement of routing emerge with scale of operation and require demand that is sufficient to form a network of flights.

To address the challenge of low load factor, this article investigates theoretical possibilities of designing a service model that facilitates sharing flights among passengers. The proposed solutions are passenger pooling and scheduled services that rely on Information and Communication Technologies (ICT) capabilities to coordinate orders and improve utilization of aircraft.

The remainder of the article is organized as follows: section 2 includes an analysis of customers. Section 3 provides overview of the proposed service model. Section 4 presents a case scenario. Section 5 discusses the results and concludes the article.

\section{PASSENGERS - THE CUSTOMERS}

The basic identified segments of passengers are leisure and business travelers [5]. The main added value that air transport provide is fast travel, albeit more expensive in terms of monetary cost, compared with other transport modes: car, bus or train. Because of higher sensitivity to value of time and lower sensitivity to price, businessmen are natural target for air transport [12], [5].

Figure 2 shows customer profile, based on canvas proposed in [13]. "Customer Jobs" are tasks that customers complete. Identified business jobs are direct contact with customers, partners, or employees. "Gains" are benefits that customer desire, that help them in completing their tasks. Identified needs are fast and easy accessibility to any location. "Pains" are obstacles that prevent completion of the identified tasks. Found pains are need and costs of additional accommodation, wear and tear in travel as well as unproductive time wasted in travel. 


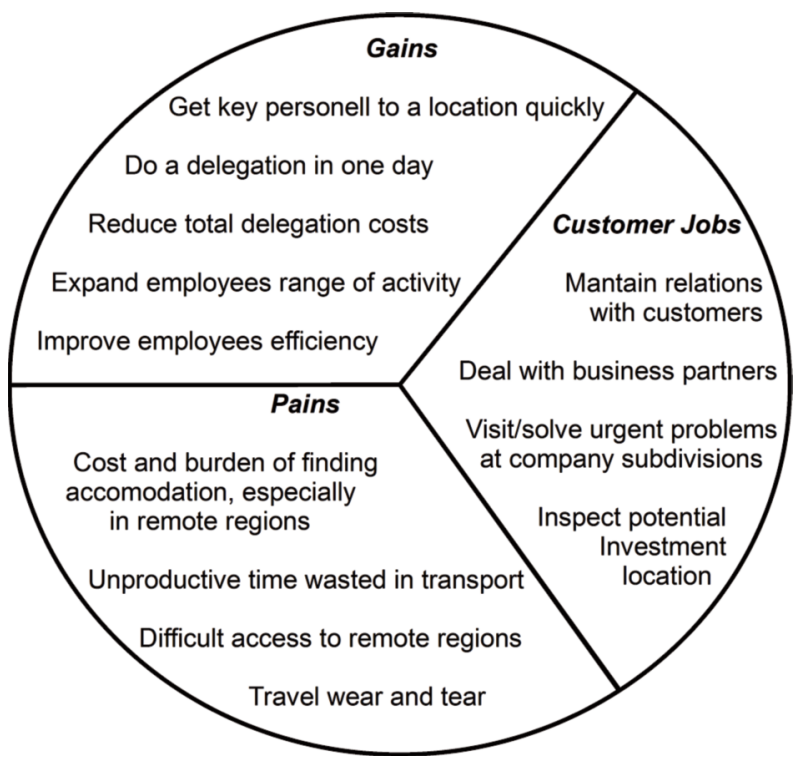

Fig. 2. Customer profile based on the canvas by [13].

\section{THE SERVICE MODEL}

The considered transport service is direct, point-to-point transport of passengers between aerodromes. To address customer needs (see Figure 2), we consider three variants of service:

- full on-demand,

- passenger pooling,

- scheduled flights.

Figure 3 shows differences in operation of the three service models.

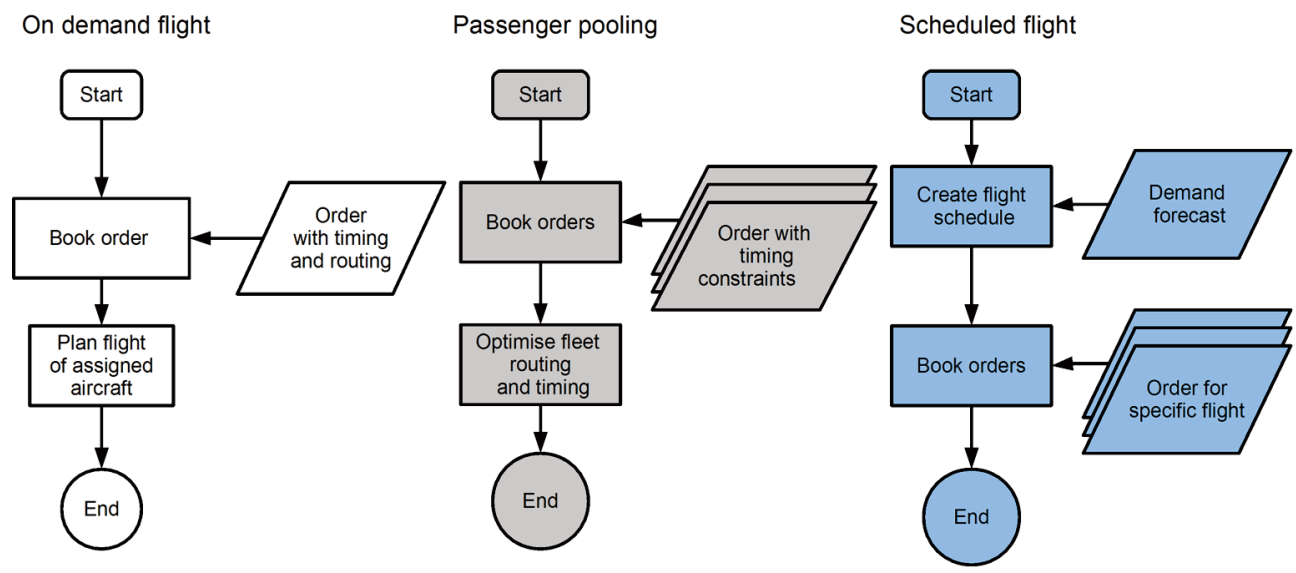

Fig. 3. Simplified flowcharts showing on-demand, passenger pooling and scheduled flights. 
Full on-demand service is a regular air taxi model. Aircraft, flight timing and routing are assigned to each order exclusively. This service variant is fully adapted to passenger timing needs and provide some privacy during travel. Detailed flight information can be available on order.

Passenger pooling is the proposed improvement over the full on-demand. It requires sufficient demand so that coordination of orders would be possible. Passenger timing is constrained by time of getting to the airport and time of arrival at destination. Coordination of orders requires meeting these constraints by multiple orders. Arrival information can be provided to passenger on order, detailed information is available shortly before flight. More customers travelling in the same aircraft allow distributing cost of travel among passengers.

Scheduled flights. This service model uses fixed flight schedule, optimized according to forecasted demand. Passengers get accurate information on flight timing on order. Operator takes the risk resulting from inaccuracy of the forecast. Preliminary condition for this service is existence of sufficient demand.

It is possible to combine the discussed models in one service portfolio. Any spare aircraft can be offered in full on-demand model of flight to complement scheduled or passenger pooling services.

The complete door-to-door travel requires, beside flight, also transfer of passengers to and from aerodromes. At very minimum, customers require information on transfer options. Extension of service transport to city using company cars or outsourced taxi or bus services is an opportunity for extra income for the operator and satisfaction for the customer.

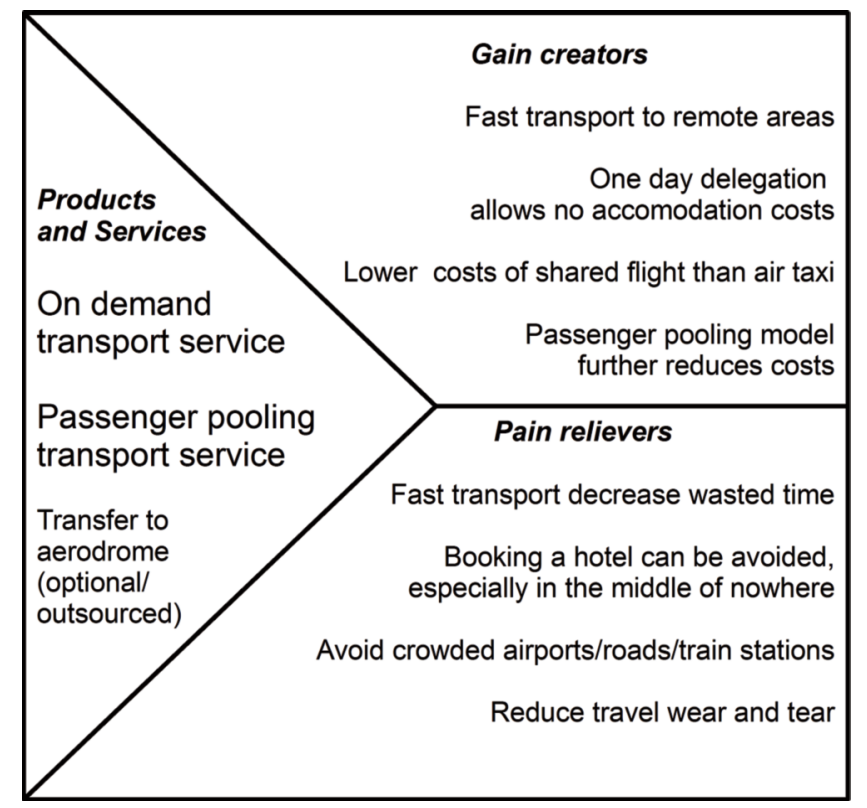

Fig. 4. Value map of the service, based on canvas in [14].

Transport service value map (see Figure 4), is based on canvas proposed in [14]. It addresses customer needs identified in the customer profile (see Figure 2). The part "Product and services" is a list of the offered services: full on-demand, passenger pooling and scheduled flights. "Gain creators" are service features that enable or at least help customers carry out their jobs. Air transport superior speed allows getting to a location within range of an airfield quickly. Network of airfields, where smaller aircraft can operate is much larger than air ports, required by airliners. Air taxi is fast mean of transport, provided that high cruise speed can outmatch extra time needed to get to and from an aerodrome in a complete door-to-door journey. Previous research assume 250-300 km [8], [5] to be the boundary distance of 
travel [5], above which air transport becomes advantageous to car and bus. Fast train can be more competitive also above these distances, although its availability is limited by its infrastructure network. "Pain relievers" are service features that help customers to overcome obstacles (pains) to fulfilling their tasks (jobs). Fast travel shortens total trip time and can eliminate a need for overnight stay, reducing cost, wasted time, as well as wear and tear of employees during travelling.

Despite the full on-demand service is fully adjusted to customer requirements, it is questionable whether absolute adaptation of timing is really important for a customer. Time of arrival must not be later than customer requires, while time of departure can vary more. Passenger pooling and scheduled services enable customers to do a business trip in one day within hundreds of kilometers radius.

\section{CASE SCENRIOS}

In order to compare and verify efficiency of each operation model we will evaluate them in three theoretical test scenarios. The goal of the tests is to see what load factor each model can yield under varying demand conditions and what percentage of potential orders can be serviced. The scenarios ignore influence of prices on the demand in the presented cases. For simplicity of calculations and clarity of the results, we will limit scale of the scenarios to one day of operations with small air taxi company operating three Cessna 172 aircraft. Assuming one pilot passenger flight is allowed, three passenger seats in three aircraft yield total capacity of nine passengers. Number of destinations is limited to three only. All connections are round trips originating from the home base of the air taxi company to avoid routing considerations. Empty legs are important problem left for another study

Each passenger trip requirements are modeled with five parameters: origin, destination, earliest time of departure, latest time of departure (LTD), earliest time of arrival (ETA) and latest time of arrival (see Figure 5). Without loss to generalization, in all the test cases, origin of each passenger will be the operator's home base.

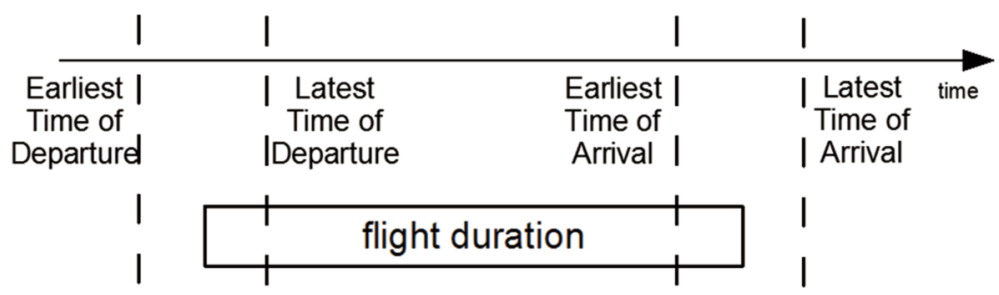

Fig. 5. Single flight model.

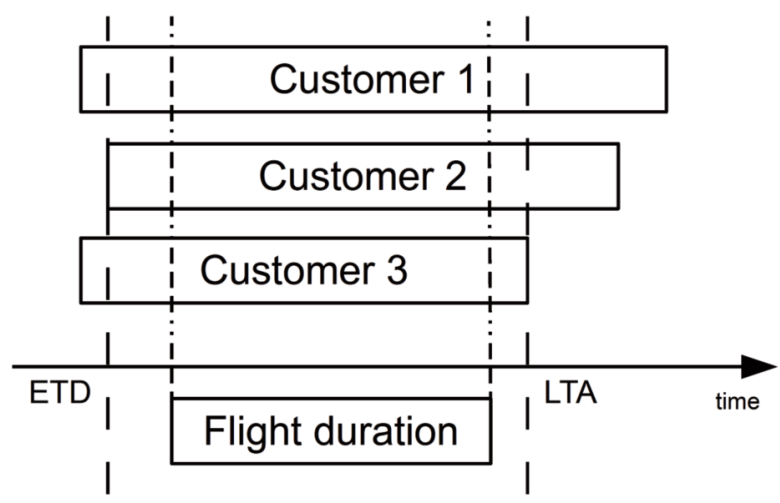

Fig. 6. Single flight meeting coordinated trip conditions. 
The Earliest Time of Departure (ETD) and the Latest Time of Arrival (LTA) among passengers limit possibilities of sharing travel. As long as difference between these constraints is longer than the planned flight duration, there is room for a single flight that meets all the customer's requirements (see Figure 6).

Network of connections, as Figure 7 shows comprises three aerodromes. Poznań Kobylnica (EPPK), Warszawa Babice (EPBC) and Katowice Muchowiec (EPKM) are sport airfields considered for use in small scale passenger transport. They are located in three voivodships with the highest Gross Domestic Product (GDP) in Poland [15].

Table 1. Scheduled flights.

\begin{tabular}{l|ccc}
\multicolumn{1}{l}{ Flight } & Route & Departure & Arrival \\
\hline 1 & $1-2$ & $08: 45$ & $09: 27$ \\
2 & $2-1$ & $15: 45$ & $16: 27$ \\
3 & $1-3$ & $09: 30$ & $10: 11$ \\
4 & $3-1$ & $16: 15$ & $16: 56$
\end{tabular}

Calculations for every model constitute a separate "what-if" sub scenario. Load factors are computed under that assumption that each model is the only one in operation. Scheduled model timing and routing is the same in all the scenarios (see Table 1). The timing and routing for on-demand and passenger pooling are optimized during calculations of solutions to minimize number of flights while servicing as much passengers as possible. Each assignment of a passenger of flight must provide round trips only, with at least 4 hours' time between flights.

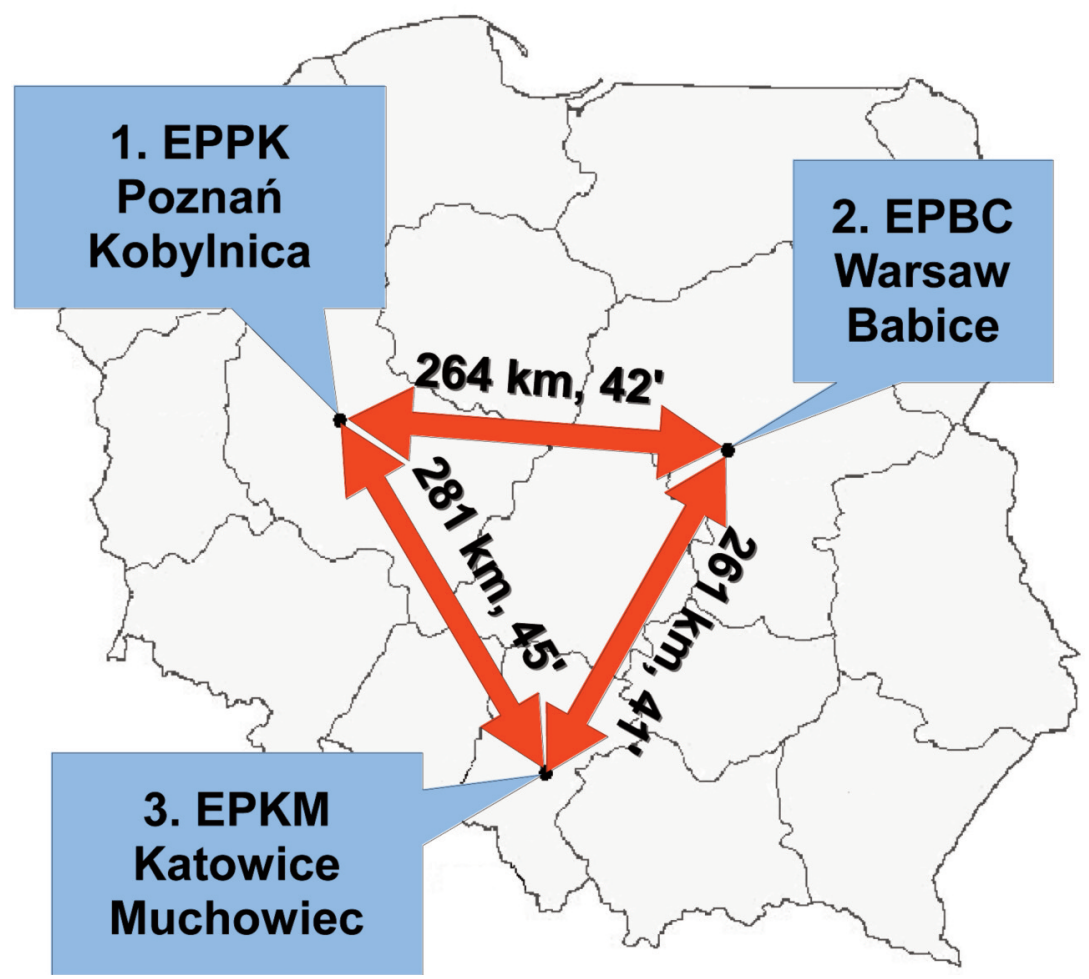

Fig. 7. Aerodromes network for case scenarios. 
Methodology of optimization used is evolutionary algorithms. The cases are simple enough for the reader to calculate his own solutions. To assign passenger to a flight, both origin and destination have to be the same and moreover, passenger time requirements have to be met by flight departure and arrival.

In all the scenarios, aircraft fleet comprise 2 aircraft A and B (both are Cirrus SR-22), stationed at airport 2. EPBC at the beginning of the day. Both aircraft are expected to return to the same airport at the end of the day.

\section{Scenario 1: Predictable demand.}

In this scenario (see Table 2 for input demand), predictable demand allowed operator to adapt the schedule to maximize the load factor and routing of its aircraft fleet. The scenario will test scheduling in its optimal environment against the other two.

Tab. 2. Scenario 1 input: passenger demand.

\begin{tabular}{l|ccc}
\multicolumn{1}{l}{ Pax } & Route & ETD & LTA \\
\hline 1 & $2-1,1-2$ & $08: 15$ & $16: 45$ \\
2 & $2-1,1-2$ & $08: 30$ & $17: 00$ \\
3 & $2-1,1-2$ & $08: 30$ & $16: 45$ \\
4 & $2-3,3-2$ & $09: 00$ & $16: 30$ \\
5 & $2-3,3-2$ & $09: 00$ & $17: 30$ \\
6 & $2-3,3-2$ & $09: 30$ & $17: 30$
\end{tabular}

Table 3, 4, and 5 show flight routing and timing for scheduled, passenger pooling and full on-demand models respectively, as well as achieved load factor for each flight. Figure 8, 9, and 10 show each passenger time for travel (difference between the ETD and LTA) as well as assigned flights (to and from destination).

Tab. 3. Scenario 1 scheduled flights.

\begin{tabular}{c|ccccc} 
Aircraft & Flight & Route & Departure & Arrival & Load Factor \\
\hline A & S1A1 & $2-1$ & $08: 45$ & $09: 27$ & $100 \%$ \\
& S1A2 & $1-2$ & $15: 45$ & $16: 27$ & $100 \%$ \\
B & S1B1 & $2-3$ & $09: 30$ & $10: 11$ & $100 \%$ \\
& S1B2 & $3-2$ & $16: 15$ & $16: 56$ & $100 \%$
\end{tabular}

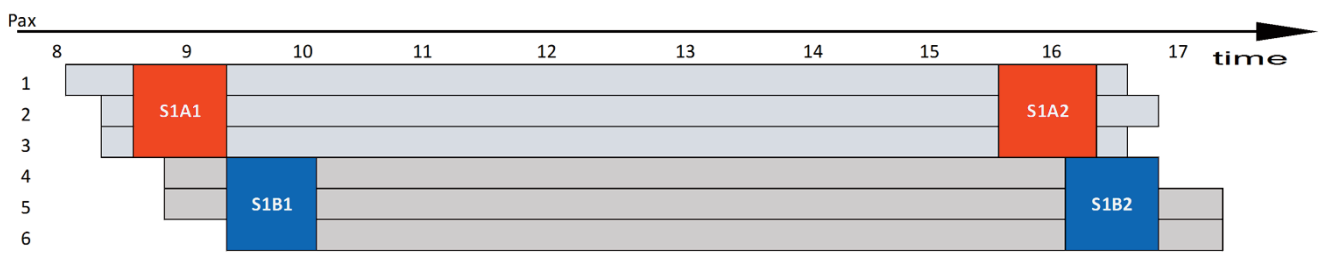

Fig. 8. Scenario 1 scheduled solution: passenger timing conditions and flight assignment. 
Tab. 4. Scenario 1 passenger pooling flights.

\begin{tabular}{c|ccccc} 
Aircraft & Flight & Route & Departure & Arrival & Load Factor \\
\hline A & P1A1 & $2-1$ & $08: 30$ & $09: 12$ & $100 \%$ \\
& P1A2 & $1-2$ & $16: 03$ & $16: 45$ & $100 \%$ \\
B & P1B1 & $2-3$ & $09: 30$ & $10: 11$ & $100 \%$ \\
& P1B2 & $3-2$ & $16: 19$ & $16: 00$ & $100 \%$
\end{tabular}

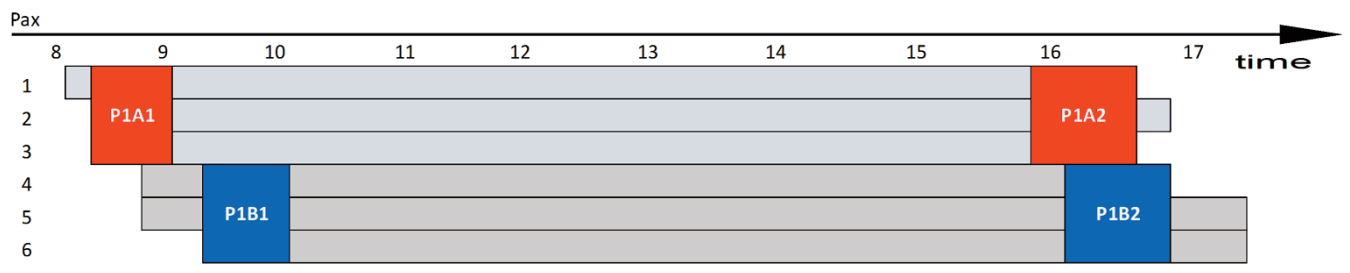

Fig. 9. Scenario 1 passenger pooling solution: passenger timing conditions and flight assignment.

Tab. 5. Scenario 1 full on-demand flights.

\begin{tabular}{c|ccccc}
\multicolumn{1}{c}{ Aircraft } & Flight & Route & Departure & Arrival & Load Factor \\
\hline A & D1A1 & $2-1$ & $08: 15$ & $08: 57$ & $33 \%$ \\
& D1A2 & $1-2$ & $09: 18$ & $10: 00$ & $0 \%$ \\
& D1A3 & $2-1$ & $10: 18$ & $11: 00$ & $33 \%$ \\
& D1A4 & $1-2$ & $14: 18$ & $15: 00$ & $33 \%$ \\
& D1A5 & $2-1$ & $15: 18$ & $16: 00$ & $0 \%$ \\
& D1A6 & $1-2$ & $16: 18$ & $17: 00$ & $33 \%$ \\
& D1B1 & $2-3$ & $09: 00$ & $09: 41$ & $33 \%$ \\
& D1B2 & $3-2$ & $10: 00$ & $10: 41$ & $0 \%$ \\
& D1B3 & $2-3$ & $11: 00$ & $11: 41$ & $33 \%$ \\
& D1B4 & $3-2$ & $14: 30$ & $15: 11$ & $33 \%$ \\
& D1B5 & $2-3$ & $15: 30$ & $16: 11$ & $0 \%$ \\
& D1B6 & $3-2$ & $16: 49$ & $17: 30$ & $33 \%$
\end{tabular}

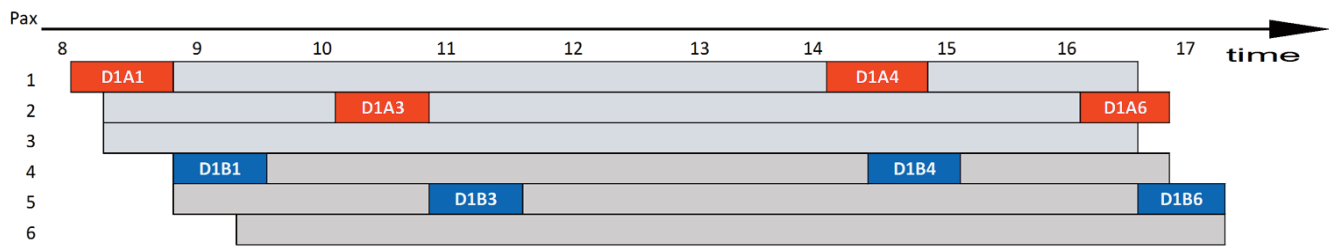

Fig. 10. Scenario 1 full on-demand solution: passenger timing conditions and flight assignment.

Results for sscenario 1 (see Table 6): Reliable prediction of demand allows scheduling to achieve the optimum load factor. Aircraft pooling, however is capable of assuring the same level of load factor. 
Sharing of seats in the scheduled and the pooling models allow better load factors and lower per passenger cost compared to the full on-demand model.

Tab. 6. Scenario 1 output parameters.

\begin{tabular}{l|llll} 
Model & $\begin{array}{l}\text { Average Load } \\
\text { Factor }\end{array}$ & $\begin{array}{l}\text { Number of } \\
\text { flights }\end{array}$ & $\begin{array}{l}\text { Passengers } \\
\text { serviced }\end{array}$ & $\begin{array}{l}\text { Rejected } \\
\text { passengers }\end{array}$ \\
\hline On-demand & $22 \%$ & 12 & 4 & 2 \\
Passenger Pooling & $100 \%$ & 4 & 6 & 0 \\
Scheduling & $100 \%$ & 4 & 6 & 0
\end{tabular}

\section{Scenario 2: One-time event.}

The scenario 2 (see Table 7) is an extension of the previous one. An event (e.g. a conference or business meeting) generates unexpected demand on one connection.

Tab. 7. Scenario 2 input: passengers demand.

\begin{tabular}{l|ccc}
\multicolumn{1}{l}{ Pax } & Route & ETD & LTA \\
\hline 1 & $2-1,1-2$ & $08: 15$ & $16: 45$ \\
2 & $2-1,1-2$ & $08: 30$ & $17: 00$ \\
3 & $2-1,1-2$ & $08: 30$ & $16: 45$ \\
4 & $2-3,3-2$ & $09: 00$ & $16: 30$ \\
5 & $2-3,3-2$ & $09: 00$ & $17: 30$ \\
6 & $2-3,3-2$ & $09: 30$ & $17: 30$ \\
7 & $1-3,3-1$ & $09: 15$ & $17: 30$ \\
8 & $1-3,3-1$ & $09: 30$ & $17: 30$ \\
9 & $1-3,3-1$ & $09: 45$ & $17: 00$
\end{tabular}

Tab. 8. Scenario 2 scheduled flights.

\begin{tabular}{c|ccccc} 
Aircraft & Flight & Route & Departure & Arrival & Load Factor \\
\hline A & S2A1 & $2-1$ & $08: 45$ & $09: 27$ & $100 \%$ \\
& S2A2 & $1-2$ & $15: 45$ & $16: 27$ & $100 \%$ \\
B & S2B1 & $2-3$ & $09: 30$ & $10: 11$ & $100 \%$ \\
& S2B2 & $3-2$ & $16: 15$ & $16: 56$ & $100 \%$
\end{tabular}

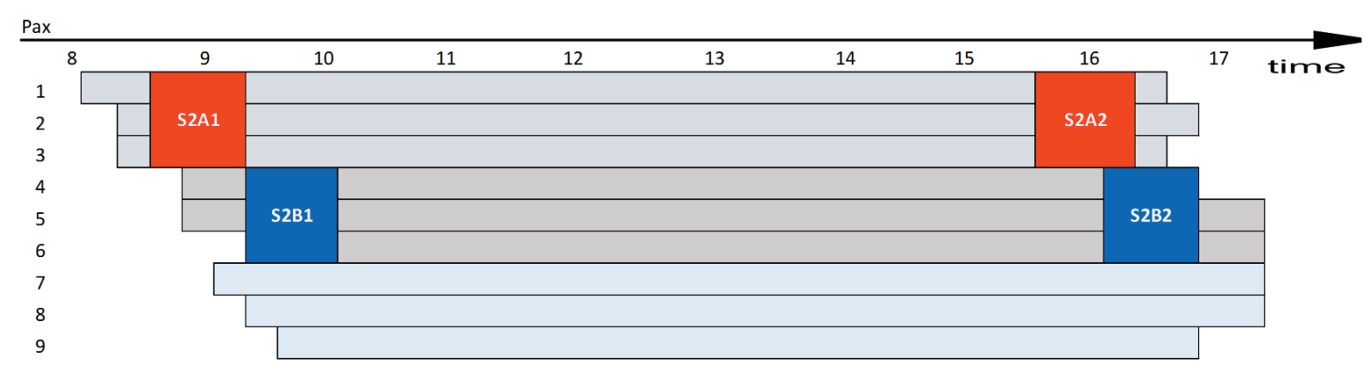

Fig. 11. Scenario 2 scheduled solution: passenger timing conditions and flight assignment. 
Tab. 9. Scenario 2 passenger pooling flights.

\begin{tabular}{c|ccccc}
\multicolumn{1}{c}{ Aircraft } & Flight & Route & Departure & Arrival & Load Factor \\
\hline A & P2A1 & $2-1$ & $08: 30$ & $09: 12$ & $100 \%$ \\
& P2A2 & $1-3$ & $09: 30$ & $10: 12$ & $100 \%$ \\
& P2A3 & $3-1$ & $15: 00$ & $15: 45$ & $100 \%$ \\
& P2A4 & $1-2$ & $16: 03$ & $16: 45$ & $100 \%$ \\
B & P2B1 & $2-3$ & $09: 30$ & $10: 11$ & $100 \%$ \\
& P2B2 & $3-2$ & $16: 19$ & $17: 00$ & $100 \%$
\end{tabular}

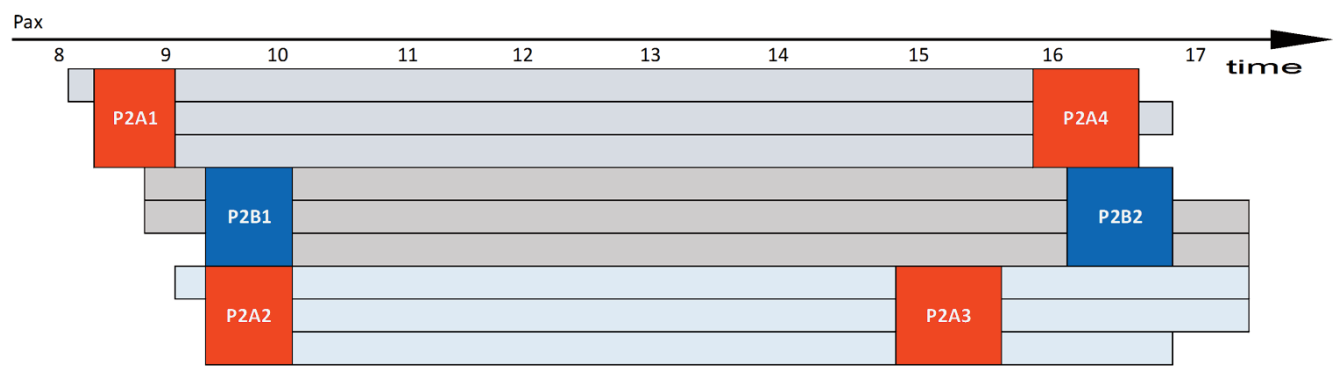

Fig. 12. Scenario 2 passenger pooling solution: passenger timing conditions and flight assignment.

Tab. 10. Scenario 2 full on-demand flights.

\begin{tabular}{c|ccccc}
\multicolumn{1}{c}{ Aircraft } & Flight & Route & Departure & Arrival & Load Factor \\
\hline \multirow{4}{*}{ A } & D2A1 & $2-1$ & $08: 15$ & $08: 58$ & $33 \%$ \\
& D2A2 & $1-3$ & $09: 15$ & $10: 00$ & $33 \%$ \\
& D2A3 & $3-2$ & $10: 19$ & $11: 00$ & $0 \%$ \\
& D2A4 & $2-1$ & $11: 18$ & $12: 00$ & $33 \%$ \\
& D2A5 & $1-3$ & $13: 00$ & $13: 45$ & $0 \%$ \\
& D2A6 & $3-1$ & $15: 45$ & $16: 30$ & $33 \%$ \\
& D2A7 & $1-2$ & $16: 48$ & $17: 30$ & $33 \%$ \\
& D2B1 & $2-3$ & $09: 00$ & $09: 41$ & $33 \%$ \\
& D2B2 & $3-1$ & $10: 00$ & $10: 45$ & $0 \%$ \\
& D2B3 & $1-3$ & $11: 00$ & $11: 45$ & $33 \%$ \\
& D2B4 & $3-1$ & $12: 15$ & $13: 00$ & $0 \%$ \\
& D2B5 & $1-2$ & $13: 18$ & $14: 00$ & $33 \%$ \\
& D2B6 & $2-3$ & $14: 18$ & $15: 00$ & $0 \%$ \\
& D2B7 & $3-1$ & $15: 18$ & $16: 00$ & $33 \%$ \\
& D2B8 & $1-2$ & $16: 18$ & $17: 00$ & $33 \%$
\end{tabular}

Table 8, 9, and 10 show flight routing and timing for scheduled, passenger pooling and on-demand models respectively, as well as achieved load factors for each flight. Figure 11, 12, and 13 show each 
passenger time for travel (difference between the ETD and LTA) as well as assigned flights (to and from destination).

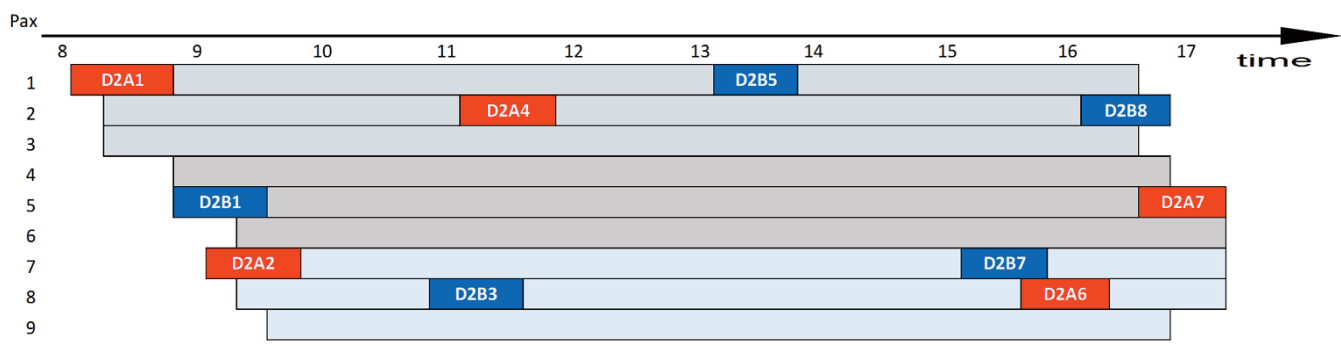

Fig. 13. Scenario 2 full on-demand solution: passenger timing conditions and flight assignment.

Results for Scenario 2 (see Table 11): This scenario shows strength in adaptability of the passenger pooling model. Schedule is dependent on reliable prediction and is inefficient at taking advantage of emerging opportunities. The on-demand model, as previously, yields worse load factor than the other ones.

Tab. 11. Scenario 2 output parameters.

\begin{tabular}{l|llll} 
Model & $\begin{array}{l}\text { Average Load } \\
\text { Factor }\end{array}$ & $\begin{array}{l}\text { Number of } \\
\text { flights }\end{array}$ & $\begin{array}{l}\text { Passengers } \\
\text { serviced }\end{array}$ & $\begin{array}{l}\text { Rejected } \\
\text { passengers }\end{array}$ \\
\hline On-demand & $22 \%$ & 15 & 5 & 4 \\
Passenger Pooling & $100 \%$ & 6 & 9 & 0 \\
Scheduling & $100 \%$ & 4 & 6 & 3
\end{tabular}

\section{Scenario 3: Chaotic demand.}

In scenario 3 (see Table 12), customers demand is highly varied to make any synchronization of orders difficult.

Tab. 12. Scenario 3 input: passengers demand.

\begin{tabular}{l|ccc}
\multicolumn{1}{l}{ Pax } & Route & ETD & LTA \\
\hline 1 & $2-1,1-2$ & $08: 30$ & $17: 15$ \\
2 & $2-1,1-2$ & $12: 30$ & $18: 15$ \\
3 & $2-1,1-2$ & $09: 00$ & $16: 15$ \\
4 & $2-3,3-2$ & $11: 30$ & $18: 15$ \\
5 & $2-3,3-2$ & $09: 30$ & $17: 00$ \\
6 & $2-3,3-2$ & $08: 30$ & $16: 00$
\end{tabular}

Table 13, 14, and 15 show flight routing and timing for scheduled, passenger pooling and on-demand models respectively, as well as achieved load factor for each flight. Figure 14, 15, and 16 show each passenger time for travel (difference between the ETD and LTA) as well as assigned flights (to and from destination). 
Tab. 13. Scenario 3 scheduled flights.

\begin{tabular}{c|ccccc} 
Aircraft & Flight & Route & Departure & Arrival & Load Factor \\
\hline A & S3A1 & $2-1$ & $08: 45$ & $09: 27$ & $33 \%$ \\
& S3A2 & $1-2$ & $15: 45$ & $16: 27$ & $33 \%$ \\
B & S3B1 & $2-3$ & $09: 30$ & $10: 11$ & $33 \%$ \\
& S3B2 & $3-2$ & $16: 15$ & $16: 56$ & $33 \%$
\end{tabular}

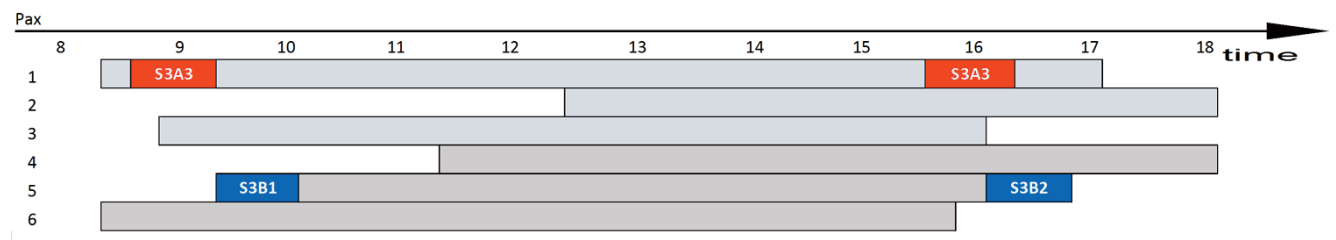

Fig. 14. Scenario 3 scheduled solution: passenger timing conditions and flight assignment.

Tab. 14. Scenario 3 passenger pooling flights.

\begin{tabular}{c|ccccc}
\multicolumn{1}{c}{ Aircraft } & Flight & Route & Departure & Arrival & Load Factor \\
\hline A & P3A1 & $2-1$ & $09: 30$ & $10: 12$ & $67 \%$ \\
& P3A2 & $1-2$ & $10: 48$ & $11: 30$ & $0 \%$ \\
& P3A3 & $2-1$ & $12: 30$ & $13: 12$ & $33 \%$ \\
& P3A4 & $1-2$ & $15: 30$ & $16: 12$ & $67 \%$ \\
& P3A5 & $2-1$ & $16: 33$ & $17: 15$ & $0 \%$ \\
& P3A6 & $1-2$ & $17: 30$ & $18: 15$ & $33 \%$ \\
& P3B1 & $2-3$ & $09: 30$ & $10: 11$ & $67 \%$ \\
& P3B2 & $3-2$ & $10: 30$ & $11: 11$ & $0 \%$ \\
& P3B3 & $2-3$ & $11: 30$ & $12: 11$ & $33 \%$ \\
& P3B4 & $3-2$ & $15: 19$ & $16: 00$ & $67 \%$ \\
& P3B5 & $2-3$ & $16: 19$ & $17: 00$ & $0 \%$ \\
& P3B6 & $3-2$ & $17: 19$ & $18: 00$ & $33 \%$
\end{tabular}

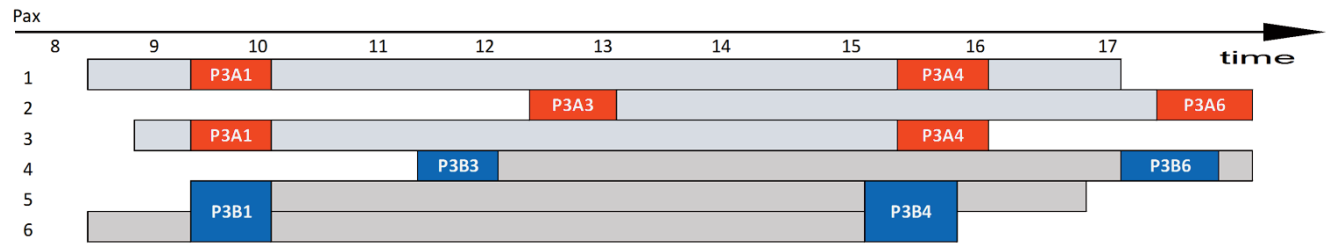

Fig. 15. Scenario 3 passenger pooling solution: passenger timing conditions and flight assignment. 
Tab. 15. Scenario 3 full on-demand flights.

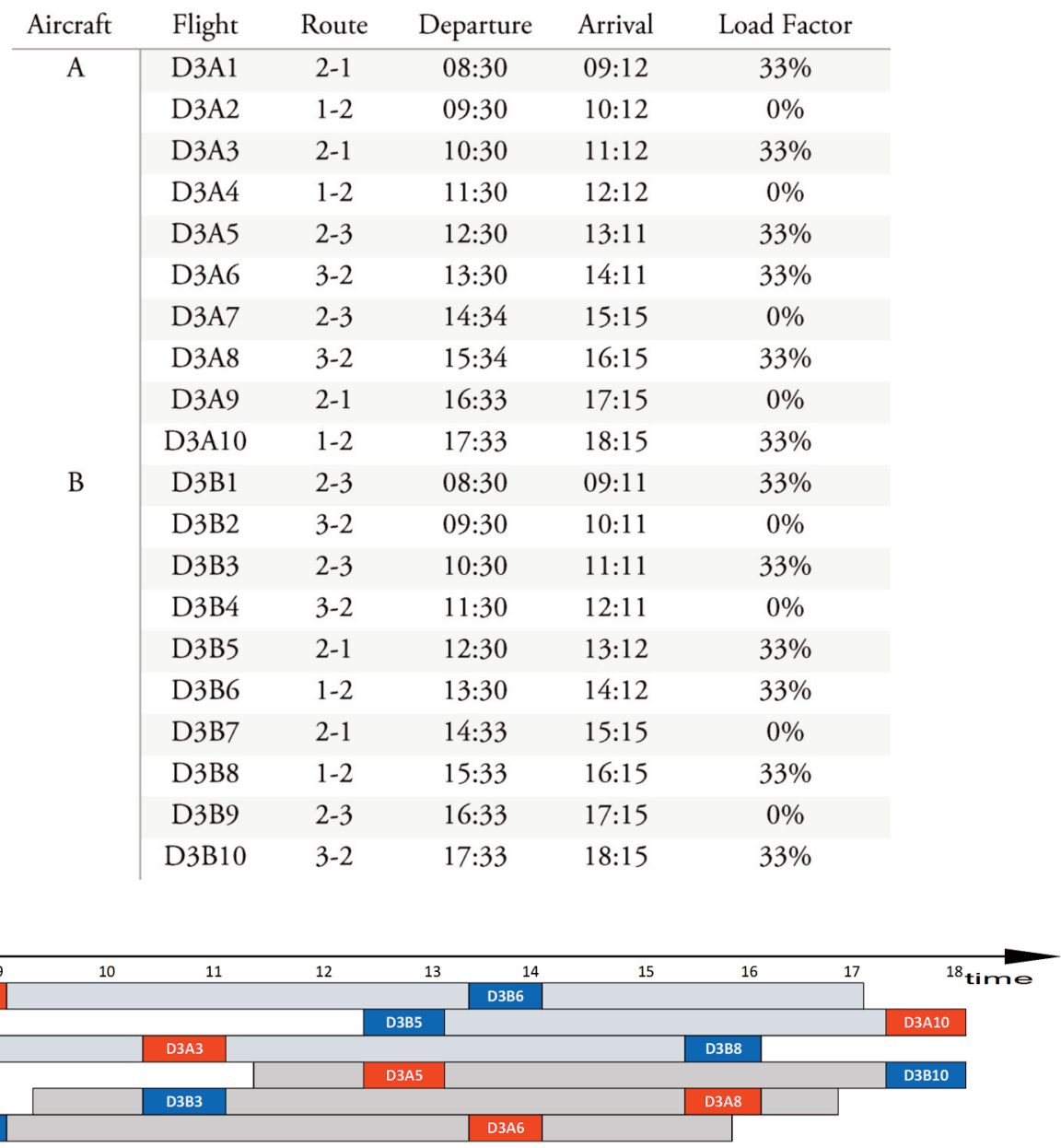

Fig. 16. Scenario 3 full on-demand solution: passenger timing conditions and flight assignment.

Results for scenario 3 (see Table 16): This scenario shows that scheduled model is vulnerable to variance in demand, as resulting load factor is low. The on-demand model, as previously, yields low load factor and large amount of flight legs because of no possibility to share seats among separate orders. The passenger pooling model allowed servicing all the passengers with fewer flights than the on-demand model.

Tab. 16. Scenario 3 output parameters.

\begin{tabular}{l|llll} 
Model & $\begin{array}{l}\text { Average Load } \\
\text { Factor }\end{array}$ & $\begin{array}{l}\text { Number of } \\
\text { flights }\end{array}$ & $\begin{array}{l}\text { Passengers } \\
\text { serviced }\end{array}$ & $\begin{array}{l}\text { Rejected } \\
\text { passengers }\end{array}$ \\
\hline On-demand & $20 \%$ & 20 & 6 & 0 \\
Passenger Pooling & $33 \%$ & 12 & 6 & 0 \\
Scheduling & $33 \%$ & 4 & 2 & 4
\end{tabular}




\section{CONCLUSIONS}

The presented case scenarios indicate that the passenger pooling and scheduled flights allow operator to achieve increased load factors and fewer flight legs, compared to the full on-demand model. Scheduled flights require sufficient stable demand to be viable.. The passenger pooling model is the most flexible of the considered models and it is the most efficient one in covering the demand. The presented theoretical tests indicate its good performance regarding load factor, not less than the scheduling and better the on-demand model. The challenge that remains for passenger pooling is customer response to approximate travel times. Further research is needed for service marketing. From operational point of view, the proposed Passenger Pooling service model facilitates sharing of flights and can improve load factor and number of passengers that can fly [6].

\section{REFERENCES}

[1] Biscardi, M., Buran, A., Haines, M., Kalss, S., Mahapatra, A., Nuoffer, J., Pinto, K., Quek, J., Nand, D. M. R., Pirie-Jacobs, C., Rattan, A., Ross, K., Singh, S., Staverman, P. and Tanner, D., 2018, "Global Business Travel Forecast 2018," American Express Global Business Travel, https://www.amexglobalbusinesstravel.com/content/uploads/2018/01/GBT-Forecast-2018FINAL.pdf

[2] Stimson, N. „TRAVELDOO,” 0407 2019. [Online]. Available: https://www.traveldoo.com/en/global-business-travel-forecast-2019/

[3] Sheehan, J. J., 2013, Business and Corporate Aviation Management, 2nd Ed., McGraw-Hill Education.

[4] Metz, N. S. and Bowen, B. D., 2004, "Agate Outcomes Analysis: Using the Foundation for SATS," Journal of Aviation/Aerospace Education \& Research, vol. 13, no 2, pp. 43-60.

[5] Baron, A., 2015, Interregional air transport. Introduction to the problem, (in Polish). Warsaw: Institute of Aviation. ISBN 978-83-63539-14-6.

[6] Laplace, I., Chertier, C., Baron, A. and Mączka, M., 2010, "Synthesis of EPATS demand estimaion," Transactions of the Institute of Aviation, vol. 3, no. 205, pp. 67-81.

[7] Laplace, I., Ghijs, S. and Rohacs, D., 2011, "D1.2 Small air tranport aircraft demand," SAT-Rdmp consortium. http://epats.eu/SATRdmp/Files/Deliverables/SAT-Rdmp-D1_2-Report-V1.pdf

[8] Baron, A. (Ed.), 2009, "R8.1 Summary of the results of work and recommendations for the Transport Development Strategy in Poland," (in Polish). STMS Consortium, Warsaw.

[9] Łukasik, B., 2017, "Analysis of the possibility of using full-electric, hybrid and turbo-electric technologies for future aircraft," (dissertation).Warsaw: Institute of Aviation.

[10] Roskam, D. J., 2015, Airplane Design Part VIII: Airplane Cost Estimation: Design, Development, Manufacturing and Operating (Volume 8), DARcorporation.

[11] Gnarowski, W., Pokorski, M. and Zdrojewski, W., 2008, “D4.2 Operating Cost Analysis," EPATS Consortium, Warsaw.

[12] Ghijs, S., Rohacs, D. and Curran, R., 2012, "D2.1 Business case subscriptions with operational characteristics," SAT-Rdmp consortium.

[13] Osterwalder, A., Pigneur, Y. and Smith, A., 2010, Business Model Generation: A Handbook for Visionaries, Game Changers, and Challengers by Alexander Osterwalder Paperback, John Wiley and Sons.

[14] Osterwalder, A., Pigneur, Y., Bernarda, G., Smith A. and Papadakos, T., 2014, Value Proposition Design: How to Create Products and Services Customers Want, John Wiley and Sons. 
[15] Statistical Office in Katowice, Centre for Regional Accounts, 2019, „Gross domestic product regional accounts in the years 2015-2017," Statistical Office in Katowice, Katowice, from https://stat.gov.pl/en/topics/national-accounts/regional-accounts/gross-domestic-product-regionalaccounts-in-the-years-2015-2017,1,18.html

\title{
WSPÓŁDZIELENIE LOTÓW TAKSÓWKAMI POWIETRZNYMI
}

\begin{abstract}
Abstrakt
W tradycyjnym modelu działania taksówek powietrznych, trasa i czas lotu są przydzielane do każdego zamówienia z osobna, co jest przyczyną minimalnego wykorzystania miejsc, maksymalnej liczby pustych przelotów i wyższych cen. Współdzielenie przelotów, gdy tylko jest możliwe, pozwala na zmniejszenie liczby niewykorzystanych miejsc i rozdzielenie kosztów przelotu między pasażerami. Wyzwaniami pozostającymi do pokonania są różne potrzeby czasowe klientów i zmienność zapotrzebowania. W niniejszym artykule przeanalizowano możliwości synchronizacji zamówień pasażerów. W zaproponowanym modelu gromadzenia zamówień konkretne czasy oferowanych lotów zastępuje się limitami: czasu najpóźniejszy przylotu i najwcześniejszego wylotu, w celu zapewnienia pola manewru do koordynacji zamówień, wykorzystując wsparcie sieciowych technologii informatycznych. Koncepcja została zweryfikowana poprzez obliczenia dla teoretycznych przypadków testowych, pozwalających na porównanie jej z tradycyjnymi lotami na żądanie i rozkładowymi.
\end{abstract}

Słowa kluczowe: taksówki powietrzne; model usługi; współdzielenie usług; współczynnik załadowania. 